\title{
New records of benthic marine algae from Morocco
}

\author{
Mustapha Hassoun, Hanaa Moussa, Ghizlane Salhi, Hanaa Zbakh, Hassane Riadi \& Mohamed Kazzaz \\ Applied Phycology-Mycology Group, Ecology, Biodiversity and Environment Laboratory, Department of Biology, Faculty \\ of Sciences, Abdelmalek Essaâdi University, 93000, BP. 2121, M'Hannech II, Tétouan, Morocco.
}

\author{
Correspondencia \\ M. Hassoun \\ e-mail: must.hassoun7@gmail.com \\ Recibido: 12 octubre 2018 \\ Aceptado: 21 octubre 2018 \\ Publicado on-line: noviembre 2018
}

\section{Nuevas citas de algas marinas bentónicas de Marruecos}

Key words: Algae, Atlantic Ocean, Champia compressa, Diplothamnion jolyi, Radicilingua thysanorhizans.

Palabras clave: Algae, Océano Atlántico, Champia compressa, Diplothamnion jolyi, Radicilingua thysanorhizans.
Morocco has always been an interesting field of marine research due to its vast coastline, $3500 \mathrm{~km}$ in length, and a particular geographical position between the Mediterranean Sea and Atlantic Ocean. The study of algal biodiversity in Moroccan coast started in 1892 by Bornet; followed by a number of surveys (e. g. Debray, 1897; Hariot, 1909; Sauvageau, 1913). In the first half of the 20th century, the Moroccan coast has attracted much interest of several authors such as Werner (1956) who presented some reflections about structure and zonation of algal communities in the Moroccan coast; Gattefosse et al. (1935), Dangeard (1949), Feldmann (1955), Gayral (1958), Cavassillas (1963), Riadi (1989) who studied the benthic phycoflora of the Atlantic coast, Lozano Cabo (1953), Kazzaz (1989), Gonzalez \& Conde (1991, 1994, 1995), whose studies focused especially on the Mediterranean coast.

Despite this apparent surge in phycological effort, considering the vastness of the geographic area in question and the diversity of biotopes available, most localities still remain largely unexplored, especially for deeper water flora. In general, the Moroccan coast remains poorly studied, if compared to other biogeographic regions. In recent years, there has been an increasing interest in its algal biodiversity (Riadi et al., 2013; Moussa et al., 2015; Salhi et al., 2016; Hassoun et al., 2014, 2015, 2016a-b, 2018).

All specimens examined in this study were collected from different localities in northwest of

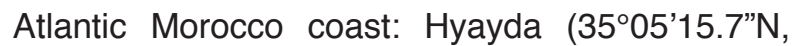
$\left.6^{\circ} 12^{\prime} 51.4 \prime \mathrm{W}\right), \quad$ Larache $\quad\left(35^{\circ} 19^{\prime} 14.58^{\prime \prime} \mathrm{N}\right.$, $\left.6^{\circ} 17^{\prime} 01.81^{\prime \prime} \mathrm{W}\right)$ and Asilah $\left(35^{\circ} 45^{\prime} 64.622^{\prime \prime} \mathrm{N}\right.$, $\left.6^{\circ} 04^{\prime} 91.00^{\prime \prime} \mathrm{W}\right)$. The study was carried out in the period 2013-2015, in the upper subtidal (0.5-1 m depth) and low intertidal of wave exposed rocky shores. Studies were carried out on samples preserved in $5 \%$ formalin-seawater solution; sections were made by hand with a razor blade. When necessary, permanent material was stained with $1 \%$ aqueous aniline blue and preserved in karo ${ }^{\circledR}$. Selected specimens were deposited in the Phycological Herbarium of the Phycology and Mycology laboratory, Faculty of Sciences, Abdelmalek Essaâdi University, Tetouan, Morocco [= HTET]. Photomicrographs were taken with an Olympus camera XC50 (Tokyo, Japan) coupled to Olympus Bx43 microscope. For nomenclatural, purposes the following taxonomic databases were used: Index Nominum Algarum (Silva, 2018) and AlgaeBase (Guiry \& Guiry, 2018).

The aim of this paper is to report three macroalgal species recorded for the first time from Morocco or from the eastern coast of the Atlantic Ocean.

\section{Radicilingua thysanorhizans (Holmes) Papenfuss (Figure 1) \\ Tetrasporophytic and vegetative specimens of Radicilingua thysanorhizans were collected from the low to mid-intertidal zone in Hyayda in March and August 2014, female gametophytes in July 2015 from Larache. The specimens were epiphytic on Cladostephus spongiosum (Hudson) C. Agardh and associated with other epiphytes, such as Centroceras clavulatum (C. Agardh) Montagne,}




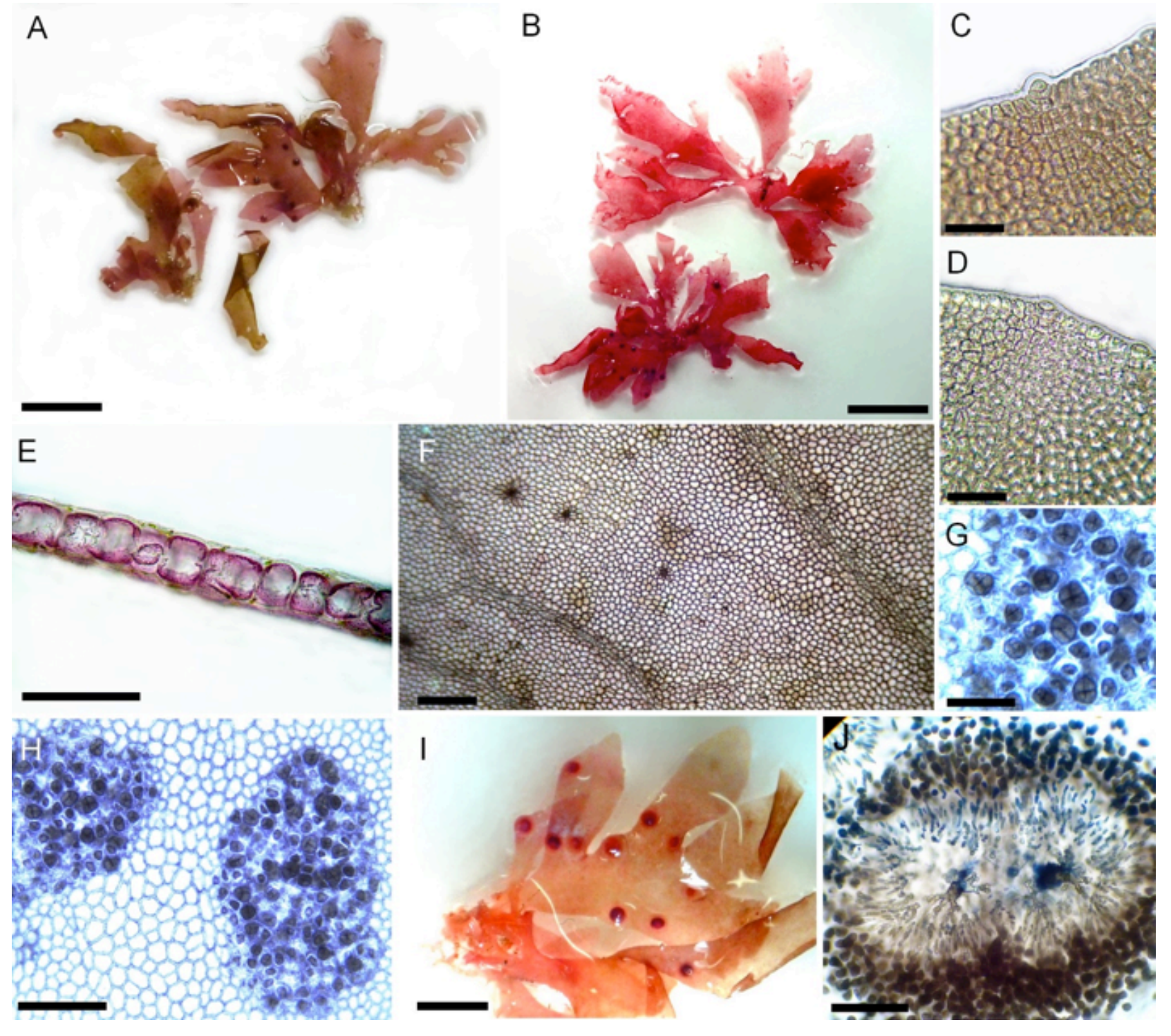

Figure 1. Radicilingua thysanorhizans, A-B: habit; C-D: apex showing the growth of thallus by transverse division of a prominent apical cell surrounded by semi-circular arrays of cells, E: transverse section of the monostromatic blade, , F: microscopic veins, G: tetrasporangia divided tetrahedrally, $\mathrm{H}$ : tetrasporangial sori, I: female blade with cystocarps, J: section through mature cystocarp with carposporangia. Scale bars: $\mathrm{A}, \mathrm{B}=2 \mathrm{~cm}, \mathrm{C}, \mathrm{D}=20 \mu \mathrm{m}, \mathrm{E}, \mathrm{G}=100 \mu \mathrm{m}, \mathrm{F}, \mathrm{J}=200$ $\mu \mathrm{m}, \mathrm{H}=150 \mu \mathrm{m}, \mathrm{l}=2 \mathrm{~mm}$.

and Ceramium spp. (HTET 884 and 891).

Thallus membranous, translucent and delicate, pale rose or/to light red, very thin, up to $6 \mathrm{~cm}$ long (Figs. 1A-B). The most divided blades consisting of irregularly dichotomously to sub-dichotomously branched segments, 3-6 $\mathrm{mm}$ wide with widely divergent branches. Blade margins entire, undulating and with rounded or pointed apices, forming marginal projections that serve to attach the blades to the substratum.

Apex showing the growth of thallus by transverse division of several apical cells, 7-8 $\mu \mathrm{m}$ in diameter (Figs. 1C-D). The blade is thin and mostly monostromatic at the upper part, about $50 \mu \mathrm{m}$ thick (Fig. 1E), and increasing in thickness near the base to $70 \mu \mathrm{m}$, with the blades becoming polystromatics. The blade comprises cells that are elongate to polygonal, pigmented, 35-90 $\mu \mathrm{m}$ long and $30-60 \mu \mathrm{m}$ wide. Midribs and macroscopic veins absent; a network of microscopic veins with a trellis-like pattern of transverse generally parallel, longitudinal are present (Figs. 1F-G).

Tetrasporangial sori are grouped into rounded or triangular near apices, singly paired on both side 

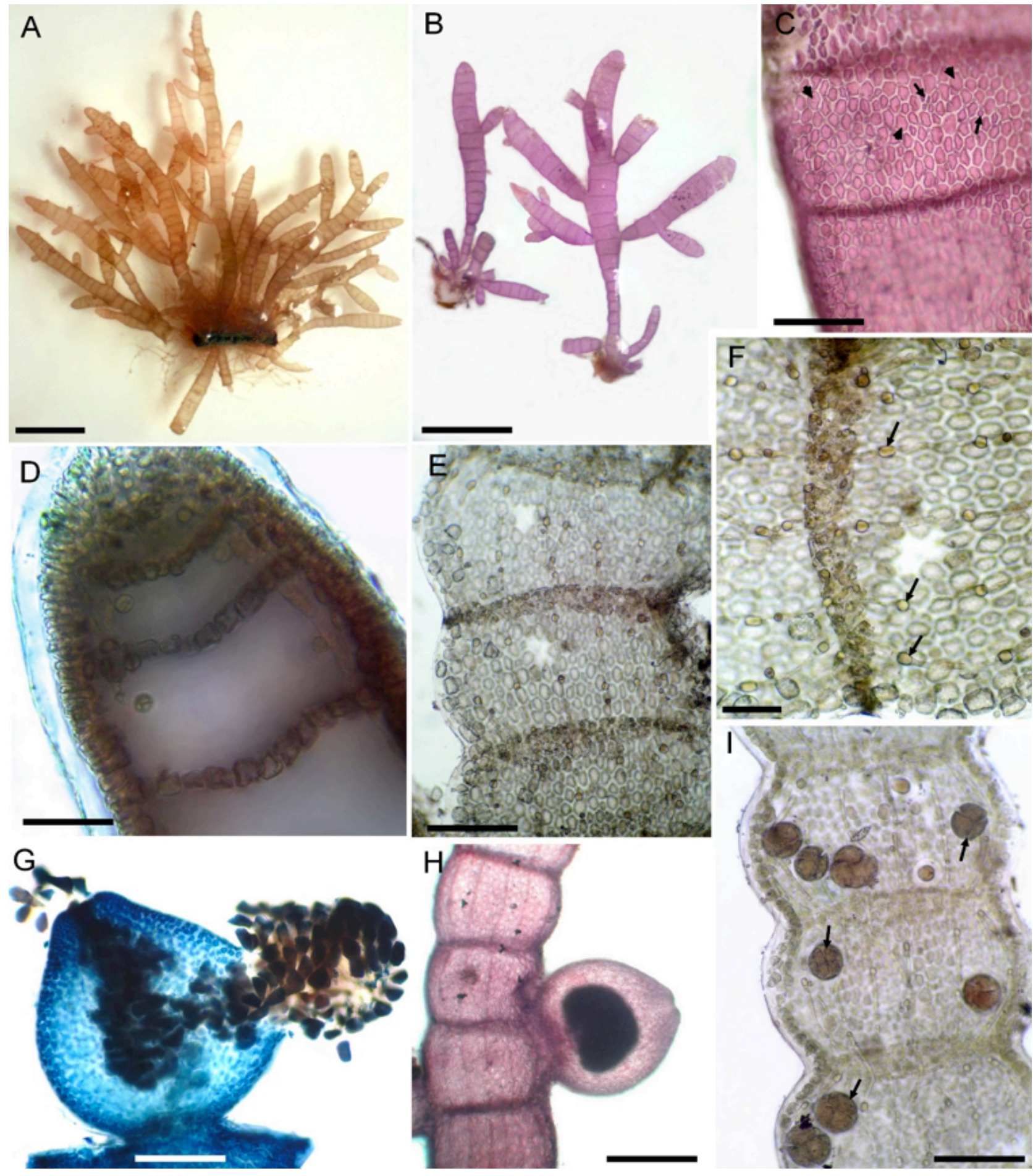

Figure 2. Champia compressa, A-B: habit, $C$ : apex in surface view showing large_(arrowheads) and small (arrows) cells, $D$ : longitudinal section showing single-layered diaphragms with 8 to 10 cells across from dorsal to ventral surfaces, E-F: longitudinal section of thallus showing longitudinal elongate medullary filaments with gland cells (arrows), G: Mature cystocarp with detail of gonimocarp containing numerous angular carposporangia, $\mathrm{H}$ : inmature cystocarp, I: longitudinal section showing tetrasporangia (arrows). Scale bars: $A, B=4 \mathrm{~mm}, \mathrm{C}, \mathrm{D}, \mathrm{E}, \mathrm{F}=150 \mu \mathrm{m}, \mathrm{G}=200$ $\mu \mathrm{m}, \mathrm{H}=300 \mu \mathrm{m}, \mathrm{l}=100 \mu \mathrm{m}$. 
of apex of blade, up to $3 \mathrm{~mm}$ wide. Tetrasporangia tetrahedrally divided, spherical, 25-40 $\mu \mathrm{m}$ in diameter (Fig. 1H). Cystocarps formed on both side of blade, scattered, spherical to hemispherical, up to $500 \mu \mathrm{m}$ in diameter when mature and with slightly protruding ostiole (Figs. 1l-J).

This species, originally described as Nitophyllum thysanorhizans Holmes 1873, based on specimens from Torpoint, Cornwall, England, is also known from Britain (Newton, 1931) as Rhizoglossum thysanorhizans (Holmes) Kylin 1924. $R$. thysanorhizans widely distributed in the Mediterranean Sea, all previous records outside the Mediterranean coast are limited to northern Atlantic Ocean of Europe and its distribution into the Atlantic Ocean regions of Africa has been enlarged in this study.

\section{Champia compressa Harvey (Figure 2)}

Tetrasporangial, female gametophytes, and vegetative specimens were collected from Hyayda in December 2013 and August 2014. From Larache in August 2014. From Asilah in February 2015. Species commonly inhabits upper sublittoral zone of rocky exposed shores, as epiphytes on Halurus equisetifolius (Lightfoot) Kützing, associated with otherepiphytes, such as Ceramium, Chaetomorpha. (HTET 744, 751, 752 and 886).

Algae are to $2 \mathrm{~cm}$ in height pale red, with 1-4 axes arising from a common holdfast; with oppositely branched, sometimes alternately; axes clearly segmented, are terete at the base, up to $500 \mu \mathrm{m}$ in diameter, increasing in diameter distally to $1-1.3 \mathrm{~mm}$ at the middle before decreasing in breadth at the apices (Figs. 2A-B).

Lateral branches are tapered at bases and apices, broader in median parts. Axes and branches are hollow, segmented, with diaphragms 8-10 cells across between the dorsal and ventral surfaces (Figs. 2C-D). The medulla consisting of longitudinal filaments of 8-18 $\mu \mathrm{m}$ in diameter and 70-200 $\mu \mathrm{m}$ long, with small spherical gland cells, up to $14 \mu \mathrm{m}$ in diameter (Figs. 2E-F).

Cystocarps are ovoid, sessile, 400-500 $\mu \mathrm{m}$ in diameter and 500-600 $\mu \mathrm{m}$ in height, with a conspicuous beak-like ostiole, carposporangia ovoid to polygonal (Figs. 2G-H). Tetrasporangia are formed in sori; mature tetrasporangia are spherical in shape, tetrahedrally divided and are $40-55 \mu \mathrm{m}$ in diameter (Fig. 2I).

This is the first record of Champia compressa from the eastern coast of the Atlantic Ocean. Champia parvula is the most common species of the genus, is widely reported throughout the world and throughout the Moroccan shores, both, Mediterranean and Atlantic coast. Some authors believe that many records need verification (Irvine \& Guiry, 1983; Lozada-Troche \& Ballantine, 2010). We believe that this view applies to many previous records of $C$. parvula from Morocco. Its diaphragms have also 8-10 cells across axes segmented, beaded (below, with cystocarps), segments about as broad as long, filled with a watery mucilag. But, it is clearly distinguished from $C$. compressa by its cylindrical axes and branching pattern (Ballantine \& Lozada Troche, 2008; N'Yeurt \& Payri, 2010; Moussa et al., 2015).

Diplothamnion jolyi C. van den Hoek (Figure 3)

This species, which was described from Klein Piscadera, Curacao, Netherlands Antilles (Van den Hoek, 1978), widely reported in the western coast of the Atlantic ocean and Pacific Islands (Guiry \& Guiry, 2018), so that their presence in Morocco merely extends their range.

Specimens were collected from Hyayda on December 2013 and August 2014. From Larache in August 2014 and in November 2015. From Asilah in Februaey 2015. This species commonly found in the upper sub-littoral, as epilithic and epiphyte on larger algae such as Corallina officinalis Linnaeus and Cystoseira tamariscifolia (Hudson) Papenfuss. (HTET 693-696).

Thallus filamentous, delicate, pink to purplishred, uncorticated, forming small tufts, up to $1 \mathrm{~cm}$ tall, without a distinct main axes (Figs. 3A-C). Consisting of extensive stoloniferous prostrate axis that give rise to numerous erect filaments.

The erect portion bears from each segment (cell) two opposite whorl-branchlets decussately arranged (Fig. 3D). The stoloniferous prostrate axis are 35-70 $\mu \mathrm{m}$ in diameter, attached to the substratum by unicellular rhizoids, $10-20 \mu \mathrm{m}$ in diameter and $200 \mu \mathrm{m}$ long and sometimes terminate in small digitate pads (Figs. 3E-F). The erect axis reaching $11 \mathrm{~mm}$ in height and 18-65 $\mu \mathrm{m}$ in diameter.

The apical cells of the whorl-branchlets are occasionally thicker than the basal cells of branches and often with an irregular outline, rounded or pointed tip or or in diminutive end cells (Figs. 3G-J).

The genus Diplothamnioncurrently represented by 4 taxa with restricted geographical distribution (Guiry \& Guiry, 2018). Originally described from the coast of southern Brazil (São Paulo), Diplothamnion is a relatively distinctive genus related in some characteristics to the Spermothamnion groupe, genus is mainly characterized by opposite decussate whorl branchlets and lack of a conspicuous fusion cell in the carposporophyte 


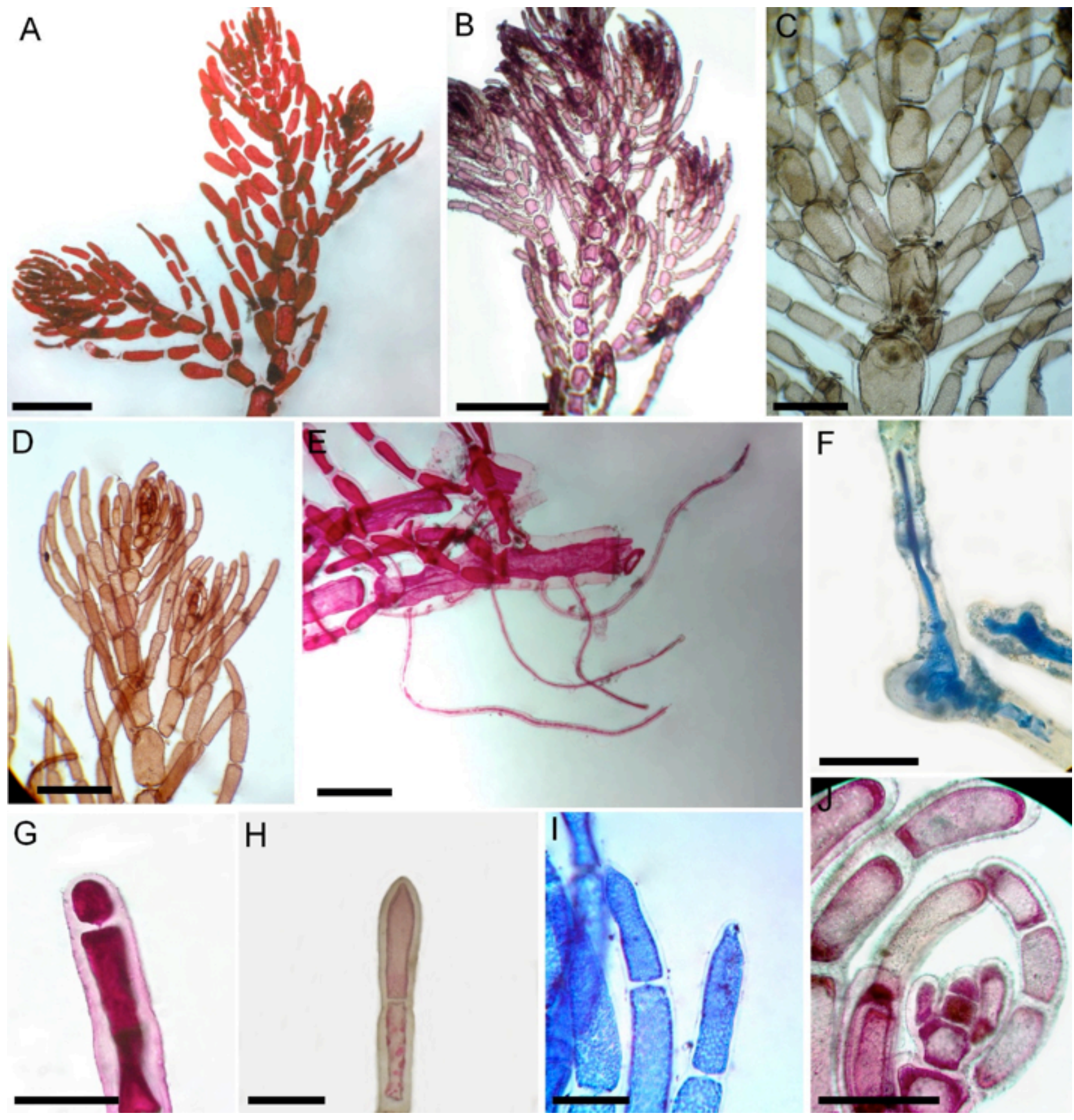

Figure 3. Diplothamnion jolyi, A-B: habit, C-D: branching pattern showing whorled branching and opposite decussate arrangement of lateral branches, E: fragment of stoloniferous basal part with unicellular rhizoids, F: detail of unicellular digitate rhizoid, G: diminutive end cell, $\mathrm{H}$-I: detail of apical cells showing apices end in apiculi, J: detail of apical cells. Scale bars: $\mathrm{A}, \mathrm{B}=200 \mu \mathrm{m}, \mathrm{C}, \mathrm{F}=100 \mu \mathrm{m}, \mathrm{G}, \mathrm{J}=50 \mu \mathrm{m}$.

(Joly et al., 1966; Huisman, 1991).

\section{References}

Ballantine, D. L., \& Lozada-Troche, C. (2008). Champia harveyana sp. nov. (Champiaceae, Rhodophyta) from Puerto Rico, Caribbean Sea. Botanica Marina, 51(5), 388-398. https://doi.org/10.1515/BOT.2008.049
Bornet, E. (1892). Les Algues de P.K.A. Schousboe récoltées au Maroc et dans la Méditerranée de 1815 à 1829 et déterminées par M. Edouard Bornet. Mémoires de la Société des sciences naturelles de Cherbourg, 28, 165-378.

Cavassillas, B. (1963). Étude morphologique, écologique et floristique du bassin D'El Harhoura. Mémoires de la Société des Sciences Naturelles et Physiques du Maroc, 3, 1-67. 
Dangeard, P. (1949). Les algues marines de la côte occidentale du Maroc. Le Botanisten, 34, 89-189.

Debray, F. (1897). Catalogue des algues du Maroc, d'Algérie \& de Tunisie. Alger: Librairie Adolphe Jourdan.

Feldmann, J. (1955). La Zonation des algues sur la Côte atlantique du Maroc. Bulletin de la Société des Sciences naturelles et physiques du Maroc, 35, 9-17.

Gattefosse, J. \& Werner, R. G. (1935). Catalogus algarum Marocanorum adhuc cognitorum. Bulletin de la Société des Sciences naturelles et physiques du Maroc, 15, 72-107.

Gayral, P. (1958). Algues de la côte atlantique marocaine. Rabat: Société des sciences naturelles et physiques du Maroc.

González García, J. A. \& Conde, F. (1991). Estudio florístico, fenológico, autoecológico y fitogeográfico del macrofitobenthos de la Mar Chica (Sebcha Buareg de Nador, Mediterráneo Marroqui). Acta Botanica Malacitana, 16, 63-80.

González García, J. A. \& Conde, F. (1994). Catalogo del macrofitobenthos del Mediterráneo de Marruecos. Acta Botanica Malacitana, 19, 5-27.

González garcía, J. A. \& Conde, F. (1995). Etude comparative sur le macrophytobenthos de trois lagunes cótieres de la Méditerrannée occidentale. Nova Hedwigia, 61, 377-390.

Guiry, M. D. \& Guiry, G. M. (2018). AlgaeBase. Worldwide electronic publication, National University of Ireland, Galway. Available at http://www. algaebase. org [Accessed 13 September 2018].

Hariot, P. (1909). Sur une collection d'algues recueillies au Maroc par M. Buchet. Bulletin du Muséum national d'Histoire naturell, Paris, 15, 128-130.

Hassoun, M., Salhi, G., Bouksir, H., Moussa, H., Riadi, H., \& Kazzaz, M. (2014). Codium tomentosum var. mucronatum et son epiphyte Aglaothamnion pseudobyssoides, deux nouvelles espèces d'algues benthiques pour la phycoflore du Maroc. Acta Botanica Malacitana, 39, 37-44.

Hassoun, M., Moussa, H., Kazzaz, M., Riadi, H., \& Salhi, G. (2015). First record of Polyneura bonnemaisonii (Delesseriaceae, Rhodophyta) from the Atlantic Ocean of Africa. Marine Biodiversity Records. https:// doi.org/10.1017/S1755267215001190

Hassoun, M., Salhi, G., Kazzaz, M., Riadi, H., \& Moussa, H. (2016a). New records of Polysiphonia sensu lato from the Atlantic Ocean in Morocco. Marine Biodiversity, 46(2), 443-449. https://doi.org/10.1007/ s12526-015-0387-8

Hassoun, M., Salhi, G., Moussa, H., Riadi, H., Kazzaz, M., \& Zbakh H. (2016b). Ceramium cornutum and Ceramium pallidum (Rhodophyta: Ceramiales) two new records for Morocco: morphology and reproductive structures. Botany Letters, 163(1), 2531. http://dx.doi.org/10.1080/12538078.2016.1142894

Hassoun, M., Wynne, M. J., Moussa, H., Salhi, G., Zbakh, H., Riadi, H., \& Kazzaz, M. (2018). An investigation of members of the tribe Ceramieae (Ceramiaceae, Rhodophyta) occurring on both the Mediterranean and Atlantic shores of Morocco. Algae, 33(3), 243-267. https://doi.org/10.4490/algae.2018.33.8.29

Huisman, I. M. (1991). Diplothamnion gordoniae sp. nov.
(Ceramiaceae, Rhodophyta) from Rottnest Island, Western Australia. Phycologia, 30, 117-123.

Irvine, L. M. \& Guiry, M. D. (1983). Rhodymeniales. In L. M. Irvine (Eds.), Seaweeds of the British Isles. Volume 1. Rhodophyta. Part 2A. Cryptonemiales (sensu stricto), Palmariales, Rhodymeniales (pp.7798). London: British Museum (Natural History).

Joly, A. B., Corderio, M., Yamaguishi, N., \& Ugadim, Y. (1966 '1965'). New marine algae from southern Brazil. Rickia, 2, 159-181.

Kazzaz, M. (1989). Contribution à l'étude de la flore algale de la région ouest de la Méditerranée. Ph.D. Thesis. Maroc: University of Mohammed V, Rabat.

Lozada-Troche, C. \& Ballantine, D. L. (2010). Champia puertoricensis sp. nov. (Rhodophyta: Champiaceae) from Puerto Rico, Caribbean Sea. Botanica Marina, 53(2), 131-141. https://doi.org/10.1515/BOT.2010.017

Lozano cabo, F. (1953). Notas sobre una prospección pesquera en la Mar Chica. Boletín Instituto Español de Oceanografía, 64, 3-37.

Moussa H., Wynne, M. J., Hassoun, M., Salhi, G., Zbakh, H., Kazzaz, M., \& Riadi, H. (2015). On the occurrence of three red algal species new to the Mediterranean Sea in Al-Hoceima National Park (Morocco). Botanica Marina, 58(6), 499-509. https://doi.org/10.1515/bot2015-0048

Newton, L. (1931). A handbook of the British seaweeds. London: British Museum (Natural History).

N'Yeurt, A. D. R. \& Payri, C. E. (2010). Marine algal flora of French Polynesia III. Rhodophyta, with additions to the Phaeophyceae and Chlorophyta. Cryptogamie Algologie, 31(1), 3-205.

Riadi, H. (1989). Étude desalgues benthiquesproductrices d'hydrocolloides (Laminaria ochroleuca et Gelidium sesquipedale). Possibilité de commercialisation de l'acide alginique. Ph.D. Thesis. Maroc: University of Mohammed V, Rabat.

Riadi, H., Salhi, G., Bouksir, H., Moussa, H., \& Hassoun, M. (2013). Acrosymphyton purpuriferum (J. Agardh) Sjöstedt et Balliella cladoderma (Zanardini) Athanasiadis, deux nouvelles espèces d'algues benthiques de la Méditerranée Marocaine. Bulletin de I'Institut Scientifique, Rabat, ection Sciences de la Vie, 35, 9-14.

Salhi, G., Hassoun, M., Moussa, H., Zbakh, H., \& Riadi, H. (2016). First record of Rhodymenia holmesii (Rhodymeniaceae, Rhodophyta) for the Mediterranean Sea from Morocco. Marine Biodiversity Records, 9(1), 62. https://doi.org/10.1186/s41200-016-0068-8

Sauvageau, C. (1913). Sur les Fucacées du détroit de Gibraltar. Compte Rendu de l'Académie des Sciences, 157, 1-3.

Silva, P. C. (2018). Index Nominum Algarum, University Herbarium. Berkeley: University of California, Available at http://ucjeps.berkeley.edu/INA. html [Accessed 13 September 2018].

Van den Hoek, C. (1978). Marine algae from the coral reef of Curaçao, Netherlands Antilles. I. Three new and one rarely observed species from the steep forereef slope. Aquatic Botany, 5, 47-61.

Werner, R. G. (1956). Réflexion au sujet de la zonation des algues au Maroc. Bulletin de la Société des Sciences Naturelles du Maroc, 36, 319-334. 